\title{
LITERASI MEMBACA UNTUK MEMANTAPKAN NILAI SOSIAL SISWA SD
}

\author{
Muhammadi, Taufina, dan Chandra \\ Pendidikan Guru Sekolah Dasar, Universitas Negeri Padang \\ email:muhammadi@fip.unp.ac.id
}

\begin{abstract}
Abstrak
Tujuan penelitian awal ini untuk mengumpulkan informasi tentang gaya belajar dan kesukaan siswa SD yang berguna untuk mengembangkan buku literasi membacasebagai bentuk pemantapan nilai sosial budaya di SD agar berdaya guna untuk Gerakan Literasi Sekolah. Hal ini dilandasi oleh masih ditemukan kasus siswa SD yang melakukan kekerasan terhadap teman sendiri. Model pengembangan literasi membaca untuk siswa SD yang digunakan adalah model Plomp dengan langkah:preliminary research, prototyping, dan assessment. Temuan penelitian dalam analisis awal yaitu siswa cenderung kurang termotivasi untuk membaca disebabkan bahan bacaan yang kurang menarik. Analisis kebutuhan menunjukkan bahwa siswa SD sangat menyukai cerita rakyat. Cerita rakyat yang perlu dikembangkan yaitu cerita rakyat nusantara yang tersebar di seluruh Indonesia dalam setiap provinsi. Diharapkan praktisi pendidikan menggunakan buku yang berisi tentang cerita rakyat dalam proses pembelajaran dan menjalankan Gerakan Literasi Sekolah. Hasil validasi bahan ajar menunjukkan bahwa bahan ajar literasi membaca dengan menggunakan cerita rakyat sudah valid dan dapat diujicobakan.
\end{abstract}

Kata kunci: literasi membaca, cerita rakyat,sekolah dasar

\section{READING LITERACY TO STRENGTHEN SOCIAL VALUES AMONG ELEMENTARY SCHOOL STUDENTS}

\begin{abstract}
This preliminary study aims to collect information about elementary school students' learning styles and preferences that are useful for developing reading literacy books to strengthenthe socio-cultural values in elementary schools in order to be effective for the School Literacy Movement. This is as based on the fact that there are cases of elementary school students committing violence against their own friends. The development model of reading literacy for elementary school students was Plomp's model with the steps of preliminary research, prototyping, and assessment. The research findings in the preliminary analysis show that students tend to have less motivation to read due to reading materials which are not interesting enough. The needs analysis results show that elementary school students really like folklore. The folklore to be developed comprises traditional Indonesian folklore spreading throughout the country in every province. It is expected that educational practitioners use a book about folklore in the learning process and the School Literacy Movement.
\end{abstract}


The results of the teaching materials validation show that reading literacy learning materials using folklore are valid and can be tried out.

Keywords: reading literacy, folklore, elementary school

\section{PENDAHULUAN}

Pemeringkatan terbaru menurut data World's Most Literate Nations, yang disusun oleh Central Connecticut State University tahun 2016, peringkat literasi Indonesia berada di posisi kedua terbawah dari 61 negara yang diteliti (Agoestyowati, 2017). Indonesia hanya lebih baik dari Bostwana, negara di kawasan selatan Afrika. Fakta ini didasarkan pada studi deskriptif dengan menguji sejumlah aspek. Antara lain, mencakup lima kategori, yaitu: perpustakaan, koran, input sistem pendidikan, output sistem pendidikan, dan ketersediaan komputer. Data yang bersumber dari kelima data tersebut memunjukkan bawa kondisi minat baca bangsa Indonesia memang cukup memprihatinkan. Perlu ada upaya daam menangani hal tersebut termasuk penyediaan bahan bacaan untuk membaca dalam pembelajaran keterampilan membaca. Baleiro (2011:17) menyatakan bahwa definisi literasi harus memperhitungkan sifat sebuah konsep yang mengkaji tentang keberadaan, kontekstual, akibatnya, relatif, dan terikat budaya. Literasi jauh lebih dari "kapasitas individu memproses informasi tertulis dalam kehidupan sehari-hari" seperti yang biasa didefinisikan. Literasi dikategorikan ke dalam tiga bentuk teks yang paling sering dijumpai peserta didik di sekolah dan dalam kehidupan sehari-hari, yaitu:literasi mengkaji tiga hal pokok, yaitu: (1) prosa narasi, teks di mana penulis menceritakan sebuah cerita, apakah fakta atau fiksi; (2) prosa ekspositori, teks di mana penulis menggambarkan, menjelaskan, atau menyampaikan informasi atau pendapat faktual; dan (3) dokumen, menampilkan informasi seperti diagram, peta, tabel, grafik, daftar, atau set instruksi (Taufina dan Chandra, 2017). Selain itu, karakteristik konteks literasi membaca diklasifikasikan empat kategori, yaitu pendidikan, pekerjaan, personal, dan masyarakat (Harsiati, 2018). Bahan ajar literasi membaca cerita rakyat perlu memperhatikan karakteristik konteks literasi membaca.

Literasi membaca yang terfokus pada membaca pemahaman mencakup empat kajian utama, yaitu: (1) keterampilan membaca; (2) penerapan, pelatihan, dan penetapan bacaan; (3) proses membaca; dan (4) teks yang digunakan dalam membaca (UNESCO, 2005:447). Ketersediaan teks serupa di atas mampu mengarahkan prestasi peserta didik dalam literasi membaca ke arah yang lebih baik (Geske dan Ozo1a, 2008:76). Literasi membaca cerita rakyat mengarahkan siswa SD menerapkan teknik membaca pemahaman. Teknik membaca pemahaman yang benar dan patut diimplementasikan, yaitu: membaca dengan tidak bersuara, bibir tidak bergerak atau komat-kamit, tidak menggerakkan kepala mengikuti baris bacaan, tidak menunjuk baris bacaan dengan jari, pensil, atau alat lainnya, dan tidak membaca kata demi kata, atau kalimat demi kalimat (Saddhono 
dan Slamet, 2012:66). Memperhatikan teknik membaca pemahaman akan melahirkan kualitas membaca peserta didik yang lebih baik.

Bahan ajar literasi membaca mengacu pada ketersediaan teks bacaan. Bahan ajar yang dikembangkan dengan strategi yang tepat akan menumbuhkan usaha kreatif penemuan sendiri isi bacaan oleh peserta didik. Proses penemuan yang dimaksud, selain mengenal jenis teks yang akan dibaca juga dapat dilakukan dengan melakukan prediksi dan meringkas isi bacaan secara tepat. Hal ini sesuai dengan pendapat Ghazali (2010:209) bahwa terdapat enam kegiatan yang dapat dilakukan dalam mencapai kesuksesan memahami isi bacaan, antara lain: (1) mengenali jenis teks, (2) mengenali beberapa macam struktur teks, (3) memprediksi dan meringkas isi dari sebuah teks atau bacaan, (4) membuat rujukan kepada informasi-informasi yang terkandung secara tersirat dalam teks, (5) menentukan makna dari kata-kata yang tidak dikenal berdasarkan konteks dari bacaan, dan (6) menganalisa morfologi dari kata-kata yang belum mereka kenal artinya.

Berdasarkan analisis kebutuhan dengan responden melalui pengamatan dan wawancara yang dilakukan oleh peneliti ditemukan beberapa permasalahan. Pertama, bahan ajar yang digunakan kurang menggambarkan proses pembelajaran literasi membaca yang tepat, sehingga pembelajaran jarang terlaksana sesuai dengan proses membaca, yaitu prabaca, saat baca, dan pascabaca. Pembelajaran membaca jarang diawali dengan adanya proses memprediksi isi bacaan karena kekurangtersediaan dalam bahan ajar yang digunakan siswa Permasalahan serupa juga ditemukan oleh Triplett (2002:123).
Kedua, bahan ajar membaca pemahaman yang digunakan di SD masih kurang membawa peserta didik untuk mengenal sosial dan budaya yang ada di lingkungan. Akibatnya, siswa jarang mengenal sosial dan budaya sekitar terutama cerita-cerita yang berkembang di lingkungan rakyat. Selain itu, Ngaka dan Masaaki (2015:90) menemukan bahwa minimnya ajakan terhadap siswa untuk mengenali sosial dan budaya mereka sendiri berdampak pada kekurangpedulian siswa terhadap lingkungan sosial dan budaya tersebut. Sementara masih ditemukan peserta didik yang kurang gemar membaca disebabkan bahan bacaan yang kurang menarik.

Ketiga, bahan ajar yang digunakan arang menggunakan cerita rakyat sebagai media pembeljaran yang berdaya guna untuk memperbaiki sikap siswa. Cerita rakyat yang ada dibiarkan hilang begitu saja, sehingga siswa kurang mengenali cerita rakyat yang ada dilingkungannya. Padaha cerita rakyat dapat menjadi salah satu bahan yang digunakan untuk mengajak siswa mengenali literasi membaca serta membentuk sikap positif sesuai dengan amanat yang terdapat di dalam cerita.

Keempat, sebagian besar peserta didik membaca dengan menyuarakan teks yang dibaca, sehingga bibirnya bergerak atau komat-kamit. Gerakan lain yang ditemukan bahwa peserta didik menggerakkan kepala mengikuti baris bacaan ketika membaca pemahaman, dan menunjuk baris bacaan dengan jari. Artinya, teknik membaca pemahaman masih jarang diaplikasikan peserta didik yang menyebabkan tingkat literasi membaca peserta didik rendah. Hal ini seiring dengan hasil studi 
pada tahun 2006 yang dilakukan oleh PISA (Programme for International Student Assessment) (Alwasilah, 2012:171).

Berdasarkan permasalahan yang teah dikemukakan, perlu dilakukan penelitian pengembangan. Salah satu solusi yang dapat dilakukan untuk meningkatkan literasi membaca siswa dalam penanaman nilai sosial budaya adalah dengan melakukan penelitian pengembangan bahan ajar literasi membaca dengan menggunakan teks cerita rakyat. Cerita rakyat dapat diartikan sebagai ekspresi budaya suatu masyarakat melalui bahasa tutur yang berhubungan langsung dengan berbagai aspek budaya dan susunan nilai sosial masyarakat tersebut. Dahulu, cerita rakyat diwariskan secara turunmenurun dari satu generasi ke generasi berikutnya secara lisan (Parmini, 2015). Cerita rakyat sangat digemari oleh warga masyarakat karena dapat dijadikan sebagai suri teladan dan pelipur lara, serta bersifat jenaka. Oleh karena itu, cerita rakyat biasanya mengandung ajaran budi pekerti atau pendidikan moral dan hiburan bagi masyarakat.

Dengan adanya cerita rakyat, diharapkan siswa dapat lebih memperhatikan teks bacaan dan meningkatkan rasa ingin tahu serta memiliki day tarik tersendiri bagi siswa terhadap teks bacaan. Sebagaimana menurut Anies Baswedan, hal yang perlu dilakukan yaitu mengajarkan anak membaca, lalu membiasakan anak membaca hingga menjadi karakter, setelah itu barulah menjadi budaya. Jadi budaya membaca itu hadir karena ada kebiasaan membaca. Kebiasaan membaca ada jika ada rencana membaca secara rutin dan rutinitas dalam baca itu penting sekali.

\section{METODE}

Model pengembangan adalah seperangkat prosedur yang berurutan untuk melaksanakan perancangan dan pengembangan pembelajaran yang diwujudkan dalam bentuk grafis (diagram) atau naratif. Model pengembangan yang digunakan dalam penelitian ini adalah model pengembangan Plomp yang diadopsi dari model pengembangan McKenney. Model Plomp terdiri atas tiga tahap, yaitu: (1) analisis pendahuluan (preliminary research), (2) perancangan (prototyping phase), dan (3) penilaian (assesment stage) (Plomp, 2013:19).

Tahap analisis pendahuluan (preliminary research) dilakukan analisis kebutuhan, analisis kurikulum, dan karakteristik peserta didik. Dilanjutkan dengan tahap perancangan (prototyping phase) dengan dibuat rancangan produk. Rancangan produk yang sudah selesai dievaluasi oleh seorang guru yang menggunakannya saat ujicoba. Aktivitas dilanjutkan dengan proses evaluasi bahan ajar lite-rasi membaca cerita rakyat oleh pakar yang biasa disebut proses validasi. Hasil konsultasi dengan pakar dijadikan sebagai masukan untuk revisi produk. Setelah direvisi, dilakukan evaluasi orang per orang dan kelompok kecil, dilanjutkan dengan ujicoba ke sekolah yang dipilih. Saat diujicobakan, diamati keterpakaian dan keterlaksanaan bahan ajar. Setelah produk direvisi berdasarkan masukan dari guru atau observer, dilanjutkan dengan ujicoba di sekolah berikutnya untuk melihat keefektifan produk(assesment stage). Pada proses akhir, diminta respon dari guru dan peserta didik, serta diuji keefektifan penggunaan bahan ajar (Tessmer dalam Plomp, 2013:36). 
Uji coba dilakukan dalam skala kecil pada tiga SD di Kota Padang. Hasil uji coba digunakan untuk mengetahui praktikalitas dan efektivitas bahan ajar literasi membaca berbasis cerita rakyat untuk SD. Uji coba untuk mengetahui kepraktisan produk dilakukan uji coba terhadap peserta didik untuk implementasi metode evaluasi oleh per orang, kelompok kecil, dan kelompok besar 1 untuk praktikalitas. Uji coba untuk mengetahui keefektifan produk dilakukan uji coba untuk implementasi metode kelompok besar 2 .

Jenis data yang diperoleh dari penelitian yaitu data kualitatif dan kuantitatif. Data kualitatif diperoleh dari hasil wawancara, pengamatan, dan catatan lapangan. Data yang bersifat kuantitatif dihimpun melalui hasil angket, lembar observasi, dan tes hasil belajar dengan menggunakan analisis data.

\section{HASIL DAN PEMBAHASAN \\ Bahan Ajar Literasi Membaca Cerita Rakyat}

Gambar yang digunakan dalam bahan ajar diperoleh dari internet yang sesuai dengan kebutuhan. Cover bahan ajar cerita rakyat dirancang dengan mengambil beberapa gambar yang mewakili isi cerita dalam buku. Bahan ajar disajikan dengan menggunakan warna yang lebih menarik dan dapat menarik perhatian siswa.

Desain cover memuat identitas/ judul bahan ajar. Hal ini dicantumkan bertujuan untuk memberikan informasi tentang gambaran dari isi bahan ajar. Desain cover bagian dalam dicetak samar pada bahan ajar dan memuat kolom identitas siswa yang beguna untuk menunjukkan identitas kepemilikan bahan ajar. Desain cover menggunakan warna dominan hijau sesuai dengan warna yang disukai siswa. Gambar yang disajikan memuat gambar yang mewakili isi bahan ajar. Gambar terdiri atas bentuk yang menggambarkan klimaks cerita rakyat.

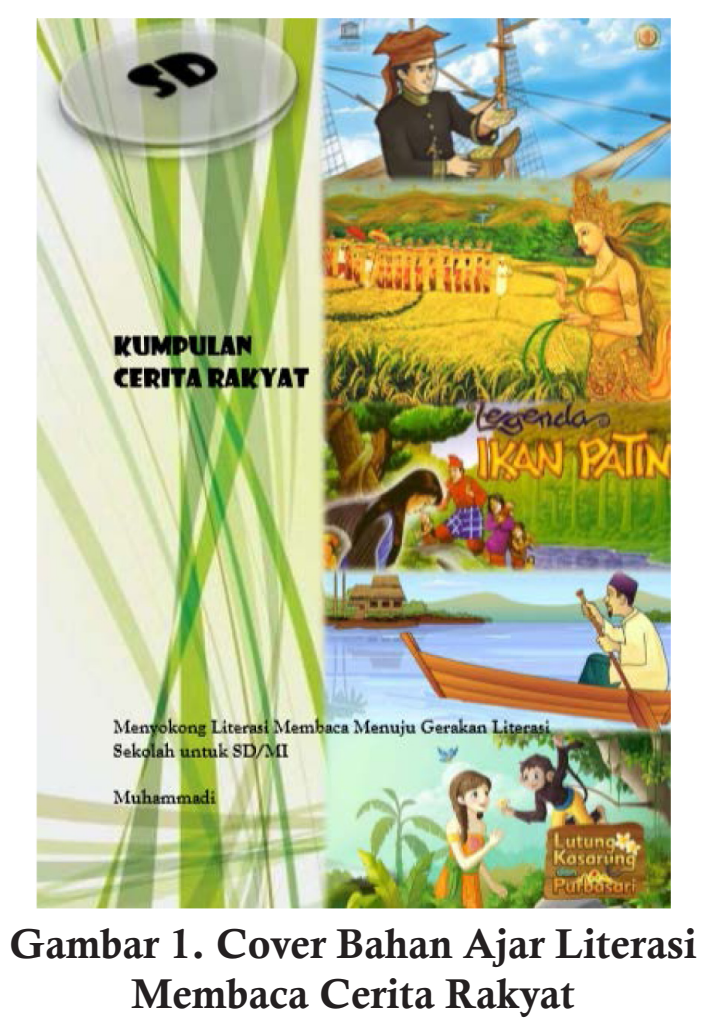

Paparan atau penyajian materi disusun sesuai dengan urutan cerita yang ada dimasing-masing provinsi. Mulai dari Indonesia Barat sampai Indonesia Timur. Isi cerita rakyat dimodifikasi dengan menerapkan komponen literasi membaca, yaitu: adanya berpikir kritis dan penanaman sikap sosial dan budaya. Salah satu contoh penanaman sikap dapat dilihat pada cerita yang berjudul "Amad Rhang Mayang". Penanaman sikap sosial dan budaya diberikan warna kuning untuk mempermudah proses validasi. Sedangkan untuk ujicoba direncanakan tidak diwarnai. 

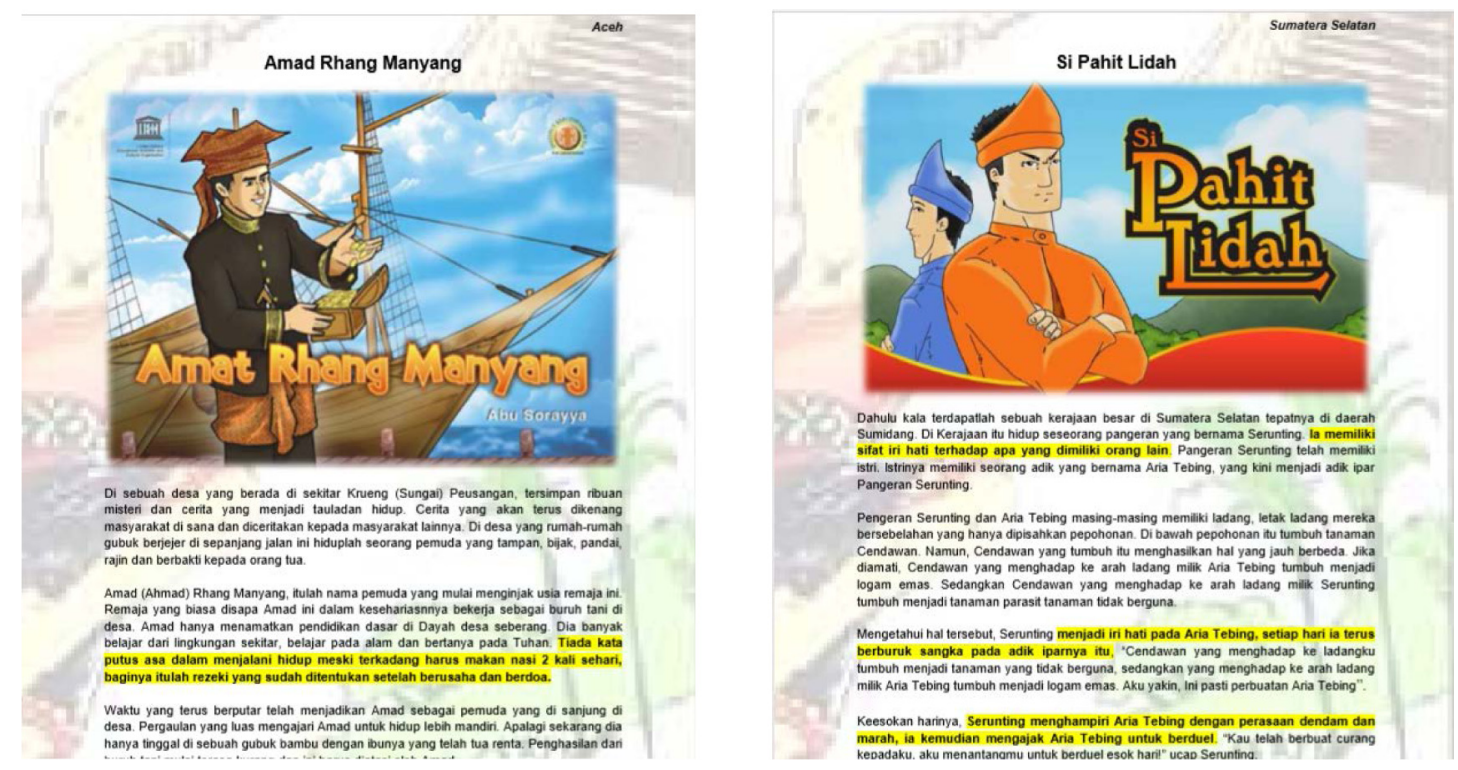

Gambar 2 Contoh Cerita Rakyat: (a) Cerita "Amad Rhang Mayang" dari Aceh di sebelah kiri dan (b) Cerita "Si Pahit Lidah" dari Sumatera Selatan di sebelah kanan

\section{Hasil Validasi Bahan Ajar Literasi Mem- baca}

Paparan yang menjadi titik fokus tentang prototype 1 yaitu hasil evaluasi prototype dengan metode expert review evaluation. Kegiatan yang dilakukan dalam proses evaluasi prototype dengan metode expert review evaluation yaitu berupa validasi bahan ajar literasi membaca dengan menggunakan cerita rakyat. Validasi dilakukan oleh 3 orang pakar.

Validasi bahan ajar dilakukan terhadap beberapa aspek, yaitu yang aspek kelayakan isi, kebahasaan, penyajian, dan kegrafikaan. Aspek kelayakan isi terdiri dari enam bagian, yaitu (1) Rancangan bahan ajar sesuai dengan karakter siswa SD. (2) Kesesuaian dengan perkembangan siswa. (3) Bahan ajar literasi membaca memuat berpikir kritis dan penanaman sikap sosial dan budaya. (4) Urutan materi pada bahan ajar sesuai dengan alur belajar yang logis dan terdapat penanaman sikap positif. (5) Bahan ajar memberi kesempatan kepada siswa dalam mengomunikasikan ide/jawaban secara individu/ kelompok. Rincian hasil validasi masing-masing aspek dapat dilihat pada beberapa tabel. Hasil validasi bahan ajar aspek kelayakan isi dapat dilihat pada tabel 1 .

Berdasarkan tabel 1 terlihat bahwa nilai rata-rata setiap indikator pada aspek kelayakan isi berada pada kategori sangat valid. Bahan ajar yang dirancang dinilai sangat sesuai dengan karakter dan perkembangan siswa SD. Bahan ajar literasi membaca cerita rakyat sudah memuat berpikir kritis dan penanaman sikap sosial dan budaya untuk siswa SD. Bahan ajar dibuat sistematis dengan memulai dari Provinsi Aceh sampai Provinsi Papua. Bahan ajar juga dinyatakan sesuai dengan perkembangan siswa. Aspek bahan ajar yang divalidasi selanjutnya adalah aspek 
Tabel 1. Hasil Validasi Bahan Ajar Aspek Kelayakan Isi

\begin{tabular}{clcc}
\hline No & \multicolumn{1}{c}{ Aspek yang Dinilai } & $\begin{array}{c}\text { Nilai } \\
\text { Validasi }\end{array}$ & Kategori \\
\hline 1. & $\begin{array}{l}\text { Rancangan bahan ajar sesuai dengan karakter siswa SD } \\
\text { 2. }\end{array}$ Kesesuaian dengan perkembangan siswa & 4 & Sangat Valid \\
3. & $\begin{array}{l}\text { Bahan ajar literasi membaca memuat berpikir kritis dan } \\
\text { penanaman sikap sosial dan budaya }\end{array}$ & 3,67 & Sangat Valid \\
4. $\quad \begin{array}{l}\text { Bahan ajar menggunakan cerita rakyat nusantara } \\
\text { 5. } \quad \begin{array}{l}\text { Urutan materi pada bahan ajar sesuai dengan alur belajar yang } \\
\text { logis dan terdapat penanaman sikap positif }\end{array}\end{array}$ & 3,89 & Sangat Valid \\
6. $\begin{array}{l}\text { Bahan ajar memberi kesempatan kepada siswa dalam } \\
\text { mengomunikasikan ide/jawaban secara individu/kelompok }\end{array}$ & $\mathbf{3}$ & Sangat Valid \\
\hline & Jumlah & $\mathbf{2 3 , 1 6}$ & Sangat Valid \\
\hline
\end{tabular}

Tabel 2. Hasil Validasi Bahan Ajar Aspek Kebahasaan

\begin{tabular}{|c|c|c|c|}
\hline No & Aspek yang Dinilai & $\begin{array}{c}\text { Nilai } \\
\text { Validasi }\end{array}$ & Kategori \\
\hline 1. & Keterbacaan & 3 & Valid \\
\hline 2. & Kejelasan informasi & 4 & Sangat Valid \\
\hline 3. & $\begin{array}{l}\text { Kesesuaian dengan kaidah bahasa Indonesia yang baik dan } \\
\text { benar }\end{array}$ & 4 & Sangat Valid \\
\hline \multirow[t]{3}{*}{4.} & Pemanfaatan bahasa secara efektif dan efisien (jelas dan singkat) & 3 & Valid \\
\hline & Jumlah & 14 & \\
\hline & Rata-rata & 3,50 & Sangat Valid \\
\hline
\end{tabular}

Tabel 3. Hasil Validasi Bahan Ajar Aspek Penyajian

\begin{tabular}{llcc}
\hline No & \multicolumn{1}{c}{ Aspek yang Dinilai } & $\begin{array}{c}\text { Nilai } \\
\text { Validasi }\end{array}$ & Kategori \\
\hline 1. & Kejelasan perumusan indikator capaian & 4 & Sangat Valid \\
2. & Urutan sajian sistematis & 4 & Sangat Valid \\
3. & Bahan ajar dapat memberi motivasi dan daya tarik & 4 & Sangat Valid \\
4. & Interaksi (pemberian stimulus dan respon) & 3 & Valid \\
5. & Kelengkapan informasi & 4 & Sangat Valid \\
\hline \multicolumn{5}{c}{ Jumlah } & $\mathbf{1 9}$ & \\
\hline Rata-rata & $\mathbf{3 , 8 0}$ & Sangat Valid \\
\hline
\end{tabular}

kebahasaan. Hasil validasi aspek kebahasaan dapat dilihat pada tabel 2 .

Berdasarkan tabel 2 terlihat bahwa secara umum validitas bahan ajar dari aspek kebahasaan berada pada kategori sangat valid. Bahan ajar literasi mem- baca diasumsikan mudah dipahami oleh siswa SD. Data didukung dengan jelasnya informasi yang disampaikan dalam bahan ajar dan sesuai dengan kaidah bahasa Indonesia. Aspek bahan ajar yang divalidasi selanjutnya adalah 
Tabel 4. Hasil Validasi Bahan Ajar Aspek Kegrafikaan

\begin{tabular}{llcc}
\hline No & \multicolumn{1}{c}{ Aspek yang Dinilai } & $\begin{array}{c}\text { Nilai } \\
\text { Validasi }\end{array}$ & Kategori \\
\hline 1. & $\begin{array}{l}\text { Penggunaan font: jenis tulisan proporsional, yaitu menggunakan } \\
\text { jenis huruf Arial }\end{array}$ & 4 & Sangat Valid \\
2. & $\begin{array}{l}\text { Penggunaan font: ukuran tulisan proporsional, yaitu } \\
\text { menggunakan ukuran 11 pada isi dan 18 pada judul subbab }\end{array}$ & 4 & Sangat Valid \\
3. Lay out atau tata letak baik & 3 & Valid \\
4. Ilustrasi, gambar, dan foto jelas & 3 & Valid \\
5. Ilustrasi, gambar, dan foto mencantumkan sumber & 3 & Valid \\
6. Ilustrasi, gambar, dan foto mewakili cerita & 4 & Sangat Valid \\
7. & Desain tampilan menarik atau tidak monoton dengan adanya & 4 & Sangat Valid \\
\hline & Jumlah & $\mathbf{1 9}$ \\
\hline
\end{tabular}

Tabel 5. Hasil Validasi Bahan Ajar Literasi Membaca secara Keseluruhan

\begin{tabular}{clccc}
\hline No & \multicolumn{1}{c}{ Aspek } & Jumlah & Rata-rata & Kategori \\
\hline 1. & Kelayakan Isi & 232 & 3,86 & Sangat Valid \\
2. & Kebahasaan & 14 & 3,50 & Sangat Valid \\
3. & Penyajian & 19 & 3,80 & Sangat Valid \\
4. & Kegrafikaan & 25 & 3,57 & Sangat Valid \\
\hline \multicolumn{7}{r}{ Total } & $\mathbf{2 9 0}$ & & \\
\hline & Rata-rata & $\mathbf{3 , 8 2}$ & & Sangat Valid \\
\hline
\end{tabular}

aspek penyajian. Hasil validasi aspek penyajian dapat dilihat pada tabel 3.

Berdasarkan tabel 3 terlihat bahwa indikator capaian telah dinilai sudah jelas dan sesuai dengan urutan penyajian yang sistematis. Penggunaan pilihan gambar dan warna yang sesuai dengan karakter siswa SD dapat memberikan motivasi dan daya tarik tersendiri untuk siswa SD sebagai pengguna bahan ajar.

Aspek bahan ajar yang divalidasi selanjutnya adalah aspek kegrafikaan. Hasil validasi aspek kegrafikaan, bahan ajar literasi membaca cerita rakyat yang telah dirancang menggunakan jenis dan ukuran font yang tepat dan terbaca oleh siswa SD. Ilustrasi bahan ajar juga sudah mewakili klimaks cerita. Secara umum validitas bahan ajar dari aspek kegrafikaan berada pada kategori sangat valid yang dapat dilihat pada tabel 4.

Berdasarkan jabaran hasil validasi dari berbagai aspek pada sebelumnya, secara keseluruhan hasil validasi dari bahan ajar literasi membaca dengan menggunakan cerita rakyat dapat dinyatakan sudah valid.

\section{Pembahasan}

Penelitian pengembangan yang dilakukan merupakan penelitian pendidikan dengan model design research yang mengembangkan suatu produk. Model 
pengembangan yang digunakan dalam penelitian diadaptasi dari model Plomp. Fokus penelitian tahun ke-1 pada tahap preliminary research atau analisis pendahuluan dan prototyping phase atau tahap perancangan menghasilkan bahan ajar yang valid.

Pengembangan bahan ajar literasi membaca dengan menggunakan cerita rakyat nusantara mengadopsi model pengembangan Plomp telah berhasil dilaksanakan dengan baik. Bahan ajar literasi membaca dengan menggunakan cerita rakyat nusantara telah divalidasi oleh para ahli. Penggunaan warna setiap cerita disesuaikan dengan gambaran umum latar cerita. Cerita didisain sesuai dengan bahasa yang mudah dipahami oleh siswa SD.

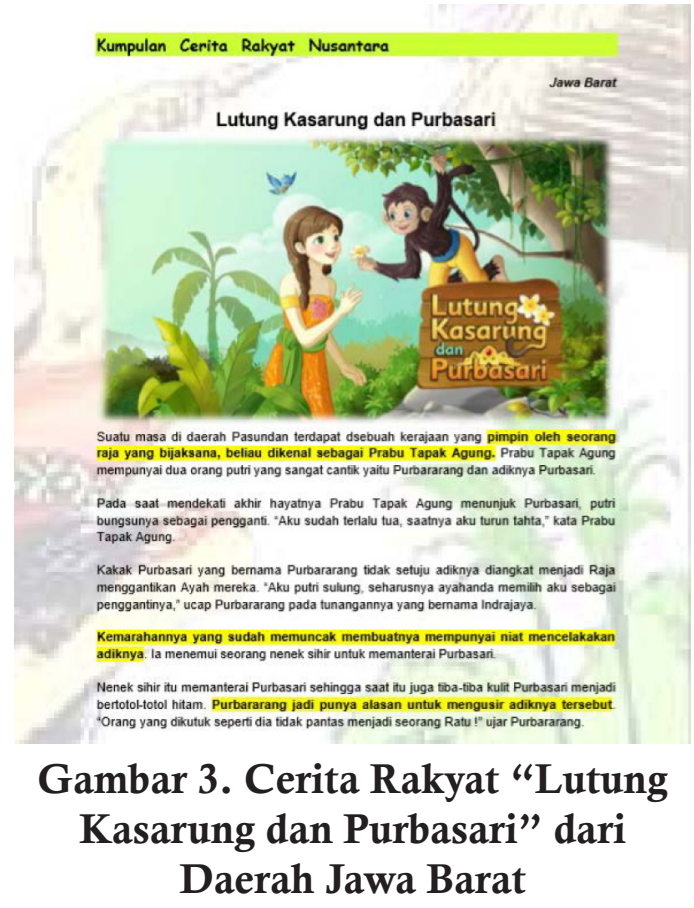

Validasi diperlukan untuk menguji suatu penelitian. Kata "valid" sering diartikan dengan tepat, benar, shahih, absah; jadi kata validitas dapat diartikan dengan ketepatan, kebenaran, ke- shahihan atau keabsahan (Sudijono, 1995:93). Bahan ajar yang telah dikembangkan dikatakan valid apabila memenuhi kriteria tertentu. Kriteria yang dimaksud seperti yang disampaikan oleh Plomp (2012:127) bahwa karakteristik dari produk yang dikatakan valid apabila terdapat merefleksikan pengetahuan (state of the art knowledge). Hal inilah yang dikatakan dengan validasi isi (content validiy). Selanjutnya, komponen-komponen produk tersebut harus konsisten satu sama lain (validitas konstruk). Oleh sebab itu, validasi yang dilakukan terhadap bahan ajar literasi membaca dengan menggunakan cerita rakyat nusantara menekankan pada validitas isi (content validity) dan validitas konstruksi (construct validity) dalam penelitian yang dilakukan.

Validasi isi telah dinyatakan valid oleh validator karena bahan ajar yang dikembangkan telah sesuai dengan materi yang sebenarnya pada pembelajaran membaca di kelas III SD dan sesuai dengan tuntutan literasi membaca yang sesungguhnya. Validitas konstruk juga telah dinyatakan valid oleh validator. Hal ini karena konstruk bahan ajar literasi membaca dengan menggunakan cerita rakyat nusantara yeng dikembangkan telah memenuhi syarat-syarat dan ketentuan penyusunan bahan ajar. Berdasarkan analisis data penilaian validasi oleh validator, bahan ajar literasi membaca dengan menggunakan cerita rakyat nusantara yang dikembangkan tergolong sangat valid. Berikut dipaparkan secara jelas uraian bahan ajar literasi membaca dengan menggunakan cerita rakyat nusantara yang telah dikembangkan.

Berdasarkan hasil analisis data validasi bahan ajar diperoleh nilai rata-rata 
3,82. Jika dilihat dari kategori yang telah ditetapkan, bahan ajar yang telah dikembangkan tergolong pada kategori sangat valid. Oleh sebab itu, dapat disimpulkan bahwa bahan ajar yang dikembangkan telah sesuai dengan tuntutan kurikulum. Penyajian materi telah sesuai dengan indikator yang dirumuskan dan sesuai dengan perkembangan peserta didik.

Isi bahan ajar juga telah sesuai dengan materi dan tuntutan literasi membaca di kelas III SD. Berbagai konsep dan penjabaran tugas-tugas yang terdapat dalam bahan ajar memudahkan peserta didik memahami isi bacaan secara tepat. Isi bahan ajar telah dapat mencapai kompetensi dasar yag dipilih. Selain itu, penggunaan bahasa dalam bahan ajar menggunakan kalimat yang sederhana dan lebih jelas, sehingga mudah dipahami oleh setiap peserta didik. Kalimat demi kalimat menggunakan ejaan yang tepat. Bahan ajar yang dikembangkan didesain dengan gradasi warna yang menarik, sehingga dapat memotivasi peserta didik untuk mengikuti proses pembelajaran dengan baik. Dengan demikian, dapat disimpulkan bahwa bahan ajar yang dikembangkan telah dinyatakan valid dan dapat digunakan dalam proses pembelajaran membaca. Selain itu, bahan ajar literasi membaca dengan menggunakan cerita rakyat nusantara juga dapat dijadikan sebagai cerita yang digunakan untuk penunjang Gerakan Literasi Sekolah (GLS) yang dicanangkan pemerintah.

\section{SIMPULAN}

Berdasarkan pengembangan dan uji coba bahan ajar yang telah dilakukan, diperoleh simpulan yaitu telah dihasilkan bahan ajar literasi membaca de- ngan menggunakan cerita rakyat nusantara yang mampu menanamkan sikap sosial dan cinta budaya siswa SD sudah siap untuk diujicobakan. Hal ini dapat dilihat berdasarkan hasil validasi bahan ajar literasi membaca dengan menggunakan cerita rakyat nusantara oleh validator yang telah dilaksanakan. Hasil ini memberi gambaran bahwa bahan ajar literasi membaca dengan menggunakan cerita rakyat nusantara yang dikembangkan telah valid dan dapat digunakan dalam proses pembelajaran membaca dan bahan cerita rakyat yang terdapat di dalam bahan ajar dapat digunakan sebagai cerita yang digunakan dalam proses Gerakan Literasi Sekolah (GLS). Diasumsikan bahwa bahan ajar literasi membaca cerita rakyat mampu menumbuhkan nilai sosial dan budaya siswa SD.

\section{UCAPAN TERIMAKASIH}

Artikel ini ditulis berdasarkan laporan penelitian produk terapan tahun 2017. Oleh karena itu, kami ucapkan terima kasih kepada UNP yang telah memfasilitasi pendanaan dalam kegiatan penelitian melalui dana PNBP UNP. Ucapan terima kasih kami sampaikan kepada kepala sekolah, guru, dan siswa SD Negeri 46 Kuranji kecamatan Kuranji dan SD Negeri 06 Padang Besi Kota Padang yang telah meluangkan waktu untuk menjadi responden dalam penelitian ini.

\section{DAFTARPUSTAKA}

Agoestyowati, Redjeki. (2017). Branding Serial KKPK: Tinjauan pada Minat Literasi Anak-anak. Majalah Ilmiah Institut STIAMI, (1) 14. Retrieved 27 Maret 2016, from http:// 
ojs.stiami.ac.id/index.php/bijak/ article/view/60/52.

Alwasilah, A. C. (2012). Pokoknya Rekayasa Literasi. Bandung: Kiblat Buku Utama.

Baleiro, R. (2011). A Definition of Literary Literacy: A Content Analysis of Literature Syllabuses and Interviews with Portuguese Lecturers of Literature. Journal of New Horizons in Education, (1) 4.Retrieved 27 Maret 2016, from http://www.tojned.net/ pdf/tojnedv01i04-02.pdf.

Binkley, M. dan Williams, T. (1996). Reading Literacy in the United States: Findings From the IEA Reading Literacy Study. Washington: Government Printing Office.

Geske, A.\& Ozola, A. (2008). Factors Influencing Reading Literacy at The Primary School Level. Journal Problems of Education in The 21st Century, (6) 1. Retrieved 11 April 2016 from http://www.jbse.webinfo.lt/71-77. Geske.pdf.

Ghazali, A. S. (2010). Pembelajaran Keterampilan Berbahasa dengan Pendekatan Komunikatif-Interaktif. Bandung: Refika Aditama.

Harsiati, Titik.2018. Karakteristik Soal Literasi Membaca pada Program PISA. LITERA, (1) 17.Retrieved 15Juli 2018from https://journal. uny.ac.id/index.php/litera/article/ view/19048.

Ngaka, W. \& Masaazi, F. Z. (2015). Participatory Literacy Learning in an
African Context: Perspectives from the Ombaderuku Primary School in the Arua District, Uganda. Journal of Language \& Literacy Education,(11) 1.Retrieved 13 Februari 2016 from http://jolle.coe.uga.edu/wp-content/uploads/2015/04/NgakaMasaazi_Final-.pdf.

Parmini, Ni Putu.(2015). Eksistensi Cerita Rakyat dalam Pendidikan Karakter Siswa $S D$ di Ubud. Jurnal Kajian Bali, (2) 5. Retrieved 13 Februari 2016 from https://ojs.unud.ac.id/ index.php/kajianbali/article/ view/16784.

Plomp, T., dkk. (2013). Educational Design Research-Part A: An Introduction. Netherlands: SLO Netherlands Institute for Curriculum Development.

Saddhono, K. dan Slamet, St.Y. (2012). Meningkatkan Keterampilan Berbahasa Indonesia (Teori dan Aplikasi). Bandung: Karya Putra Darwati.

Triplett, Cheri Foster. 2002. Dialogic Responsiveness: Toward Synthesis, Complexity, and Holism in Our Reponses to Young Literacy Learners. Journal of Literacy Research, (34) 1. Retrieved 13 Februari 2016 from http://jlr.sagepub.com/ content/34/1/119.full.pdf + html.

UNESCO. (2005). Literacy for Life. Paris (Prancis): United Nations Educational, Scientific, and Cultural Organization. 